\title{
Front Matter: Volume 8282
}

, "Front Matter: Volume 8282," Proc. SPIE 8282, Broadband Access Communication Technologies VI, 828201 (27 January 2012); doi: 10.1117/12.923839

SPIE. Event: SPIE OPTO, 2012, San Francisco, California, United States 


\title{
PROCEEDINGS OF SPIE
}

\section{Broadband Access \\ Communication Technologies VI}

\author{
Benjamin Dingel \\ Raj Jain \\ Katsutoshi Tsukamoto \\ Editors
}

24-26 January 2012

San Francisco, California, United States

Sponsored and Published by

SPIE

Volume 8282

Proceedings of SPIE, 0277-786X, v. 8282 
The papers included in this volume were part of the technical conference cited on the cover and title page. Papers were selected and subject to review by the editors and conference program committee. Some conference presentations may not be available for publication. The papers published in these proceedings reflect the work and thoughts of the authors and are published herein as submitted. The publisher is not responsible for the validity of the information or for any outcomes resulting from reliance thereon.

Please use the following format to cite material from this book:

Author(s), "Title of Paper," in Broadband Access Communication Technologies VI, edited by Benjamin Dingel, Raj J a in, Katsutoshi Tsukamoto, Proceedings of SPIE Vol. 8282 (SPIE, Bellingham, WA, 2012) Artic le CID Number.

ISSN 0277-786X

ISBN 9780819489258

Published by

SPIE

P.O. Box 10, Bellingham, Wa shington 98227-0010 USA

Telephone +1 3606763290 (Pacific Time)· Fax +1 3606471445

SPIE.org

Copyright ( 2012 , Society of Photo-Optic al Instrumentation Engineers

Copying of material in this book for intemal or personal use, or for the intemal or personal use of specific clients, beyond the fair use provisions granted by the U.S. Copyright Law is authorized by SPIE subject to payment of copying fees. The Transactional Reporting Service base fee for this volume is $\$ 18.00$ per article (or portion thereof), which should be paid directly to the Copyright Clearance Center (CCC), 222 Rosewood Drive, Danvers, MA 01923. Payment may also be made electronically through CCC Online at copyright.com. Other copying for republication, resale, advertising or promotion, or any form of systematic or multiple reproduction of any material in this book is prohibited except with permission in writing from the publisher. The CCC fee code is $0277-786 \mathrm{X} / 12 / \$ 18.00$.

Printed in the United States of America.

Public ation of record for individual papers is online in the SPIE Digital Library.

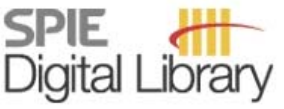

SPIEDigitallibrary.org

Paper Numbering: Proceedings of SPIE follow an e-First public ation model, with papers published first online and then in print and on CD-ROM. Papers are published as they a re submitted and meet public ation criteria. A unique, consistent, permanent citation identifier (CID) number is assigned to each artic le at the time of the first public ation. Utilization of CIDs a llows artic les to be fully citable as soon as they are published online, and connects the same identifier to all online, print, and electronic versions of the public ation. SPIE uses a six-digit CID artic le numbering system in which:

- The first four digits correspond to the SPIE volume number.

- The last two digits indicate publication order within the volume using a Base 36 numbering system employing both numera ls and letters. These two-number sets start with $00,01,02,03,04$, $05,06,07,08,09,0 A, 0 B \ldots$ OZ, followed by 10-1Z, 20-2Z, etc.

The CID numberappears on each page of the manuscript. The complete citation is used on the first page, and an abbreviated version on subsequent pages. Numbers in the index correspond to the last two digits of the six-digit CID number. 


\title{
Contents
}

\author{
$\checkmark \quad$ Conference Committee \\ vii Introduction
}

\section{OPTICAL COMMUNICATIONS PLENARY SESSION}

828202 Optical coherent technologies in next generation access networks (Plenary Paper) [8282-01]

K. Iwatsuki, NTT Corp. (Japan); K. Tsukamoto, Osaka Univ. (Japan)

\section{SESSION 1 ADVANCED SIGNAL PROCESSING: JOINT SESSION WITH CONFERENCE 8284}

828203 Optical signal processing for wireless transmission (Invited Paper) [8282-02]

T. Kawanishi, National Institute of Information and Communications Technology (Japan)

828204 Adjustable transfer function optical filter for microwave applications [8282-03] N. Madamopoulos, J. Kuang, The City College of New York (United States); A. Prescod, Corning, Inc., (United States)

SESSION 2 HIGH-CAPACITY COHERENT OPTICAL TECHNOLOGIES: JOINT SESSION WITH CONFERENCE 8284

828205 Coherent OCDMA communication systems (Invited Paper) [8282-04]

$X$. Wang, Heriot-Watt Univ. (United Kingdom)

828206 VCSEL-based optical transceiver module operating at $25 \mathrm{~Gb} / \mathrm{s}$ and using a single CMOS IC [8282-05]

G. Afriat, L. Horwitz, D. Lazar, A. Issachar, A. Pogrebinsky, A. Ran, E. Shoor, R. Bar, R. Saba, Intel Corp. (Israel)

SESSION 3 NEXT-GENERATION DEVICES AND COMPONENTS: JOINT SESSION WITH CONFERENCES 8283 AND 8284

828208 Power balancing effect on the performance of IMPACC modulator under critical coupling (CC), over coupling (OC), and under coupling (UC) conditions at high frequency [8282-07] B. B. Dingel, Nasfine Photonics, Inc. (United States); N. Madamopoulos, The City College of New York (United States); A. Prescod, Corning Inc. (United States); R. Madabhushi, Madabhushi Consultants, LLC (United States) 
8282 OB Transportation of a microwave environment over networks and the applications (Invited Paper) [8282-10]

Y. Shoji, National Institute of Information and Communications Technology (Japan)

\section{SESSION 5 RADIO-OVER FIBER COMMUNICATION AND ACCESS PRICING}

8282 OD Pricing by timing: innovating broadband data plans (Invited Paper) [8282-12]

S. Ha, C. Joe-Wong, S. Sen, M. Chiang, Princeton Univ. (United States)

8282 OF Analog photonic link by using DFB lasers operated in the low laser threshold current region and external modulation [8282-14]

A. García-Juárez, Univ. de Sonora (Mexico); I. E. Zaldívar-Huerta, Instituto Nacional de Astrofísica Óptica y Electrónica (Mexico); J. Rodríguez-Asomoza, Univ. de las Américas Puebla (Mexico); R. Gómez-Colín, A. G. Rojas-Hernández, D. Berma- Mendoza,

R. Gómez-Fuentes, A. Vera-Marquina, Univ. de Sonora (Mexico)

8282 OG Evaluation on a costless 60-GHz OFDM-based indoor wireless over multimode fiber green system employing a photonic integrated smart antenna (Invited Paper) [8282-15] S. Mikroulis, P. Sotiropoulos, E. Pikasis, Technological Educational Institute of Athens (Greece); G. Agapiou, Hellenic Telecommunications Organization (Greece)

$8282 \mathrm{OH}$ Temperature impairment characterization in radio-over-multimode fiber systems [8282-20] C. Vázquez, D. S. Montero, Univ. Carlos III de Madrid (Spain)

SESSION 6 METRO AND ALTERNATIVE ACCESS TECHNOLOGIES (VISIBLE LIGHT COMMUNICATION): JOINT SESSION WITH CONFERENCE 8283

828201 Visible light communication in dynamic environment using image/high-speed communication hybrid sensor [8282-16]

K. Maeno, M. Panahpour Tehrani, T. Fujii, H. Okada, T. Yamazato, M. Tanimoto, Nagoya Univ. (Japan); T. Yendo, Nagaoka Univ. of Technology (Japan)

8282 0J Energy efficient lighting and communications [8282-17]

Z. Zhou, M. Kavehrad, The Pennsylvania State Univ. (United States); P. Deng, Wuhan National Lab. for Optoelectronics (China)

8282 OK The Smart Room: a $100 \mathrm{Mb} / \mathrm{s}$ integrated optical access point transceiver for indoor visible light communication [8282-18]

N. B. Datiri, A. Mirvakili, C. Sthalekar, E. Fu, C. Xi, S. Nercessian, T. Shah, B. Noorani,

V. J. Koomson, Tufts Univ. (United States)

$8282 \mathrm{OL} \quad$ Hybrid positioning with lighting LEDs and Zigbee multihop wireless network [8282-19]

Y. U. Lee, S. Baang, J. Park, Hallym Univ. (Korea, Republic of); Z. Zhou, M. Kavehrad, The

Pennsylvania State Univ. (United States)

Author Index

iv 


\title{
Conference Committee
}

\author{
Symposium Chair
}

Klaus P. Streubel, OSRAM GmbH (Germany)

Symposium Cochairs

David L. Andrews, University of East Anglia Norwich (United Kingdom) Liang-Chy Chien, Kent State University (United States)

Program Track Chair

Benjamin Dingel, Nasfine Photonics, Inc. (United States)

Conference Chairs

Benjamin Dingel, Nasfine Photonics, Inc. (United States)

Raj Jain, Washington University in St. Louis (United States)

Katsutoshi Tsukamoto, Osaka University (Japan)

Program Committee

Abdel-Karim Al-Tamimi, Yarmouk University (Jordan)

Arjan Durresi, Indiana University-Purdue University Indianapolis (United States)

David W. Faulkner, British Telecom Research Laboratories

(United Kingdom)

Mahbub Hassan, The University of New South Wales (Australia)

Mohsen Kavehrad, The Pennsylvania State University (United States)

Rangaraj Madabhushi, Madabhushi Consultants, LLC (United States)

Nicholas Madamopoulos, The City College of New York (United States)

Dalma Novak, Pharad, LLC (United States)

Jean-Charles Point, JCP-Consult (France)

Ken-ichi Sato, Nagoya University (Japan)

Chakchai So-In, Khon Kaen University (Thailand)

Peter Van Daele, Universiteit Gent (Belgium)

Jeroen S. Wellen, Alcatel-Lucent (Netherlands) 
Session Chairs

Optical Communications Plenary Session

Benjamin Dingel, Nasfine Photonics, Inc. (United States)

Guifang Li, CREOL, The College of Optics and Photonics, University of Central Florida (United States)

$1 \quad$ Advanced Signal Processing: Joint Session with Conference 8284

Katsutoshi Tsukamoto, Osaka University (Japan)

Dieter Stefan Jäger, Universität Duisburg-Essen (Germany)

2 High-Capacity Coherent Optical Technologies: Joint Session with Conference 8284

Roland Ryf, Alcatel-Lucent Bell Laboratories (United States)

Benjamin Dingel, Nasfine Photonics, Inc. (United States)

3 Next-Generation Devices and Components: Joint Session with Conferences 8283 and 8284

Guifang Li, CREOL, The College of Optics and Photonics, University of Central Florida (United States)

Werner Weiershausen, Deutsche Telekom AG (Germany)

$4 \quad$ Special Session on Optical Technologies for Mobile Microwave Access

Raj Jain, Washington University in St. Louis (United States)

Katsutoshi Tsukamoto, Osaka University (Japan)

5 Radio-over Fiber Communication and Access Pricing

Katsutoshi Tsukamoto, Osaka University (Japan)

Andru J. Prescod, Corning Incorporated (United States)

6 Metro and Alternative Access Technologies (Visible Light

Communication): Joint Session with Conference 8283

Atul K. Srivastava, OneTerabit (United States)

Raj Jain, Washington University in St. Louis (United States) 


\section{Introduction}

It is our continuing pleasure to welcome all of you to the Photonics West 2012 conference on Broadband Access Communication Technologies VI. This is our sixth year and our on-going purpose is still to promote discussions and disseminations of design, development, and performance of various types of emerging broadband access communication technologies.

Since last year, we have attempted to provide an integrated program with multiple joint sessions that cut across the three optical-communication related conferences, namely;

(1) Broadband Access Communication Technologies VI,

(2) Optical Metro Networks and Short-Haul Systems IV, and

(3) Next Generation Optical Communication: Components, Subsystems, and Systems II, (formerly Coherent Optical Communication: Components, Subsystems, and Systems).

The three conferences have assembled well-known invited speakers and solicited high quality technical papers coming from Asia, Europe, and North America as evident in our programs. These excellent joint sessions are made possible through the cooperation and leadership of all conference chairs involved.

In particular, we in the Broadband Access Communication conference continue to provide discussions and disseminations for platform technologies such as optical fiber-based, radio-over-fiber-based, photonics-based, copper-based, satellite-based, mobile wireless-based and power-line communications, and emerging technologies such as green broadband access that have relevance to the optical Metro as well as to the emerging technologies of Coherent Communications. We have invited a number of well-known speakers to present the current and future trends of these broadband access technologies as well as the economics of pricing in access.

Finally, we acknowledge and appreciate the speakers and authors of all the contributed and invited papers, the technical program committee members, and SPIE staff for all their valuable efforts. The success of this conference is strongly due them.

Benjamin Dingel

Raj Jain

Katsutoshi Tsukamoto 
Downloaded From: https://www.spiedigitallibrary.org/conference-proceedings-of-spie on 26 Apr 2023

Terms of Use: https://www.spiedigitallibrary.org/terms-of-use 